\title{
ENERGY EFFICIENCY IN UKRAINE IN THE CONTEXT OF EUROPEAN PRACTICES: EDUCATIONAL ASPECT
}

\section{Nina Batechko}

ORCID iD 0000-0002-3772-4489

Doctor of Sciences in Pedagogy, Associate Professor,

Head of the Department of Higher and Applied Mathematics,

National University of Life and Environmental Sciences of Ukraine,

15 Heroyiv Oborony Str., 03042 Kyiv, Ukraine,

batechko_n_@ukr.net

\section{Olena Shelimanova}

ORCID iD 0000-0002-3321-1651

$\mathrm{PhD}$ (Technical Sciences), Associate Professor,

Associate Professor of the Department of Thermotechnics,

National University of Life and Environmental Sciences of Ukraine,

15 Heroyiv Oborony Str., 03042 Kyiv, Ukraine,

shelemanova@ukr.net

\section{Serhii Shostak}

ORCID iD 0000-0003-1234-1024

Doctor of Sciences in Pedagogy, Associate Professor,

Associate Professor of the Department of Higher and Applied Mathematics,

National University of Life and Environmental Sciences of Ukraine,

15 Heroyiv Oborony Str., 03042 Kyiv, Ukraine,

shostakserg@ukr.net

https://doi.org/10.28925/2518-7635.2019.4.6

\section{ABSTRACT}

The current tendency towards depletion of fuel and energy resources, the growth of prices on energy production and global economic problems stimulate the necessity of introduction of energy efficient technologies. Very important and relevant in this situation is the study of the experience of the EU Member States on energy efficiency in Ukraine and the direct implementation of energy saving projects in Ukraine. In these trends, modern students can and should play an active role.

The purpose of our Project is to educate a conscious and responsible future consumer of thermal and electric energy, who will conserve and use efficiently the traditional energy resources and promote the replacement of their alternative energy sources, resting upon the experience of leading $E U$ countries.

Implementation of the educational program "Energy efficiency: experience of EU countries for Ukraine" will enable popularization of EU experience in implementation 
of energy efficient technologies in different economy sectors and acquiring practical skills of project realization aimed at energy saving and reduction of negative impact on environment by future professionals.

Key words: energy efficiency, education component, European experience.

(C) Nina Batechko, Olena Shelimanova, Serhii Shostak, 2019

\section{INTRODUCTION}

The world power industry is in the process of large-scale changes. The current tendency towards depletion of fuel and energy resources, the growth of prices on energy production and global economic problems stimulate the necessity of introduction of energy efficient technologies. For Ukraine, energy efficiency means saving resources, primarily natural gas purchased abroad, as well as reducing the energy intensity of the Ukrainian economy.

The Government of Ukraine has recently adopted a number of legislative initiatives to replace natural gas (Energy Strategy of Ukraine until 2030, 2013). There are some positive movements in realization of state policy in energy-independence and energy efficiency in Ukraine? Such as adopting of Strategy of sustainable development "Ukraine - 2020" (Sustainable Development Strategy "Ukraine 2020", 2015). Ukraine's accession to the Treaty establishing the Energy Community (EC) 2010 (Protocol, 2010) and number of other initiatives.

Nevertheless, the activity in the introduction of energy-efficient technologies is slowed down both by informal lobby of traditional energy resources and by the mental habit of the population to consume "cheap" Russian gas. Such delay in this case can cost a lot to our country. Ukraine's compliance with international obligations under the Energy Charter Treaty, numerous bilateral international treaties and the requirements of European energy legislation require the intensification of state policy in this area.

Very important and relevant in this situation is the study of the experience of the EU Member States on energy efficiency in Ukraine and the direct implementation of energy saving projects in Ukraine. A significant role in this can and should be played by current students, from whom life does not require only a high level of professional training, but also a wide range of general cultural, human and life competencies. Deeper acquiring of the European experience in energy efficiency by future experts of different sectors of Ukrainian economy will allow them to use the obtained theoretical knowledge and practical skills in their professional activities and promote the best practices of the EU among the public.

\section{BACKGROUND}

For this reason, projects have been launched in many countries around the world to provide students with the necessary knowledge and practical skills in energy efficiency. 
One of the most famous is the "Green Campus" project - a socio-ecological system within the university territory where environmental and energy-saving technologies and a culture of life are introduced with the aim of solving energy and environmental problems and for the harmonious development of society and nature (Antipov et.al, 2018). The pioneers in implementing Green Campus programs were the best US universities - the University of Berkeley, Harvard University, 13 universities of the state of California and others. Later, universities in Europe and Asia joined them. However, the measures of this program are mainly aimed solely at achieving indicators of saving thermal and electric energy in the premises of higher educational institutions and at reducing harmful emissions into the atmosphere.

The purpose of our Project is to educate a conscious and responsible future consumer of thermal and electric energy, who will conserve and use efficiently the traditional energy resources and promote the replacement of their alternative energy sources, resting upon the experience of leading EU countries.

Methodological basis of research about implementation of European energy saving technologies in energy sector of Ukraine on the philosophic level is assuring the inextricable link between the theory and the practice. On the level of general scientific methodology, there is synergy of scientific approaches: system, synergetic and competent. On the level of concrete scientific methodology there are conceptual ideas of comparative analysis for implementation of progressive EU experience in energy saving. On the technological level, there are methods of research of directions of implementation of EU energy saving technologies in Ukraine (Batechko, 2017).

The main methodological question of module is how and which ways we should use modern European experience of energy efficiency in the national energy system, taking into account historical traditions and modern situation in energy sector of Ukraine.

The module is structured considering the European experience of teaching the course "Energy efficiency of enterprises", particularly in The Köln University of Applied Sciences (Köln, Germany), based on studying and comparative analysis of EC legislation in energy efficiency and energy management, documents of Organization for Economic Cooperation and Development (OECD) and statistic sources.

To reach the goal of promotion of the EU experience in energy resources saving we plan to create a web-site, as well as to involve mass media and publications in open access journals.

\section{MAIN RESULTS}

The specialists of the Educational and Scientific Institute of Energy, Automation and Energy Conservation of the National University of Life and Environmental Sciences of Ukraine in collaboration with Cologne University of Applied Sciences (Cologne, Germany) have developed the Educational Project (hereinafter the Project) "Energy Efficiency: Europe's Experience for Ukraine (EEE for Ukraine").

The project's target audience includes students of baccalaureate of most specialties in different faculties of National University of Life and Environmental Sciences 
of Ukraine on a regular basis: Faculty of Veterinary Medicine, Faculty of Plant Protection, Biotechnology and Ecology, Faculty of Livestock Raising and Water Bioresources, Faculty of Food Technology and Quality Control of Agricultural Products, Agrobiological Faculty, Economic Faculty, Faculty of Humanities and Pedagogy, Faculty of Information Technologies.

The project includes three components:

1) educational;

2) information:

3) practical.

Within the framework of the educational component of the project, the problems of the exhaustibility of energy resources, a saving attitude to them, energy production and its supply to the consumer are examined in order to encourage students to take actions to solve them.

Aimed to reach the goals of the project, the methodology of the project implies lectures, seminars and interactive lessons (see Fig.1). 30 lectures (60 hours) are planned for acquiring theoretical knowledge about energy efficiency and supporting energy saving policy in EU countries. 30 seminars (60 hours) are planned for strengthening knowledge of non-technical specialists about use of energy saving measures in industry and house holding, basing on EU experience and for implementation of European standards in Ukraine.

Aimed at forming of energy efficient thinking of students and at practical use of obtained theoretical knowledge and skills in their professional activity, the module implies interactive lessons (60 hours).

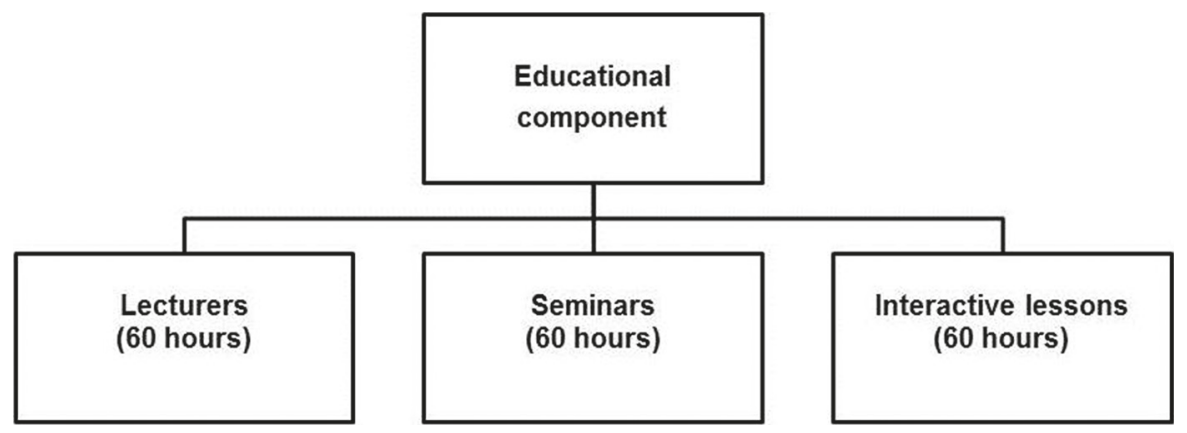

Fig.1. Training course structure

As a result, students participating in the Project will learn to understand the technical and financial problems of energy supplying enterprises; save and rationally use energy resources and timely pay for the services received.

To successfully solve the problems of energy conservation, it is necessary to make these problems relevant, socially significant in the mass consciousness, so that every Ukrainian has a new energy-efficient thinking. Therefore, as part of the course, it is planned to introduce an information campaign by the participants aimed at raising awareness of the saving attitude towards energy resources among teachers, parents, residents of the micro-district. The objectives of the information campaign are to promote: 
- $\quad$ active perception of information by people about the need for energy conservation;

- creating people's own ideas about energy conservation;

- $\quad$ attracting people to participate in energy saving measures and developing energy-saving behaviour;

- popularization of the experience of leading European countries in the implementation of energy-efficient technologies in various sectors of the economy.

To implement the objectives of the information campaign, it is appropriate to use both means of interpersonal communication, information tools aimed at a limited audience (brochures, posters, trainings, lectures (learning), individual consultations, etc.), and the media. To achieve the goal of promoting the EU's experience in energy conservation, it is planned to create a website that will also provide media support for the Project.

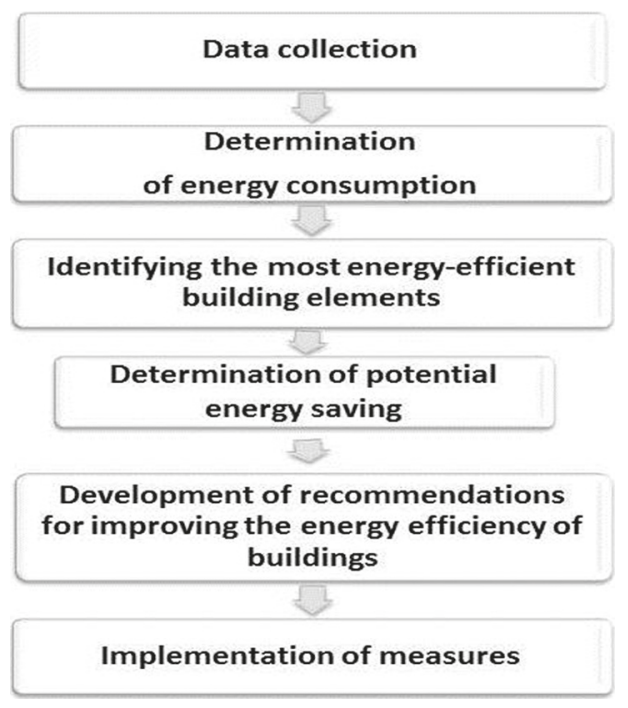

Fig. 2. Algorithm of energy audit work

The practical component assumes that upon completion of the project, its participants will adhere to energy and environmentally sound behaviour and lifestyle. At the final stage, they will have sufficient preparation to independently conduct a simplified energy audit of educational and residential premises and develop project proposals to increase their energy efficiency according to the algorithm shown in Fig.2 (Safiulina, 2010; Kozirskiy, et. al, 2012).

\section{CONCLUSIONS}

The world practice knows different methods of energy efficiency optimization including state regulation of energy saving as well as providing financial encouragement for population, important role belongs also to the promoting and educating programs. Educating methods are supposed to influence directly on consumer, forming new consumption culture, based on careful nature use and conscious choosing of energy saving technologies. 
Implementation of the educational program "Energy efficiency: experience of EU countries for Ukraine" will enable popularization of EU experience in implementation of energy efficient technologies in different economy sectors and acquiring practical skills of project realization aimed at energy saving and reduction of negative impact on environment by future professionals.

\section{Expected results}

1. Increasing the level of knowledge of future specialists on the introduction of energy-efficient technologies in the EU member states.

2. Obtaining knowledge of European standards and guidelines for legal regulation in the energy sector of the European countries.

3. Formation of the students' practical skills and skills required to meet the energy and environmentally neutral lifestyle and popularize responsible consumer behavior.

\section{REFERENCES}

Energy Strategy of Ukraine until 2030 (2013). (in Ukrainian). https://zakon.rada. gov.ua/laws/show/n0002120-13

Sustainable Development Strategy “Ukraine 2020” (2015). (in Ukrainian). https:// zakon.rada.gov.ua/laws/show/5/2015

Protocol on the Accession of Ukraine to the Treaty Establishing the Energy Community (2010). (in Ukrainian). https://zakon.rada.gov.ua/laws/show/994_ a27

Antipov, Y.O., Mishchenko, A.V., Shelimanova O.V.(2018). Sustainable Development \& “GREEN CAMPUSES" - the way to energy efficiency of universities. Scientific Bulletin of GATI SNAU. (in Ukrainian).

Batechko, N.G. (2017). Methodology of Educology: Synergetic Aspect. Educology Discourse, 1-2 (16-17), 1-12. (in Ukrainian). http://od.kubg.edu.ua/index.php/ journal/article/view/435

Safiulina, K.R. (2010). Energy Saving in Campuses. Kiev. Polygraph Plus LLC. (in Ukrainian).

Kozirskiy, V.V., Bereka, O.M., Shelimanova, O.V., Antipov, Y.O. (2012). Results of the Simplified Energy Audit of NULES of Ukraine. Energy and Automation, 1 (11), 55-63. (in Ukrainian).

\section{ЕНЕРГОЕФЕКТИВНІСТЬ В УКРАЇНI В КОНТЕКСТІ ЄВРОПЕЙСЬКИХ ПРАКТИК: ОСВІТНІЙ АСПЕКТ}

Батечко Ніна, доктор педагогічних наук, доцент, завідувач кафедри вищої та прикладної математики, Національний університет біоресурсів і природокористування України, вул. Героїв Оборони, 15, 03042 Київ, Україна, batechko_n_@ukr.net 
Шеліманова Олена, кандидат технічних наук, доцент, доцент кафедри теплотехніки, Національний університет біоресурсів і природокористування України, вул. Героїв Оборони, 15, 03042 Київ, Україна, shelemanova@ukr.net

Шостак Сергій, кандидат фізико-математичних наук, доцент, доцент кафедри вищої та прикладної математики, Національний університет біоресурсів і природокористування України, вул. Героїв Оборони, 15, 03042 Київ, Україна, shostakserg@ukr.net

Сучасна тенденція до виснаження паливно-енергетичних ресурсів, зростання иін на виробництво енергії та глобальні економічні проблеми стимулюють необхідність впровадження енергоефективних технологій. Дуже важливим та актуальним у иій ситуаціі є вивчення досвіду держав-членів ЄС щодо енергоебективності в Украӥні та безпосередня реалізація проектів з енергозбереження в Україні. Важливу роль у цьому можуть і повинні відігравати нинішні студенти,

Метою нашого Проекту є виховання свідомого та відповідального майбутнвого споживача теплової та електричної енергї̈, який буде ефективно зберігати та ефективно використовувати традиційні енергетичні ресурси та сприяти заміні альтернативних джерел енергії, спираючись на досвід провідних країн $Є C$.

Впровадження освітньої програми «Енергоефективність: досвід країн ЄС для України» дасть змогу популяризувати досвід ЄС щодо впровадження енергоебективних технологій у різних секторах економіки та набути практичних навичок реалізації проектів, спрямованих на економію енергії та зменшення негативного впливу на навколиине середовище майбутніми професіоналами.

Ключові слова: енергоефективність, складова освіти, європейський досвід.

Received: 03.12.2019

Accepted: 26.12.2019 